CRYSTALLOGRAPHIC COMMUNICATIONS

ISSN 2056-9890

Received 3 September 2019

Accepted 7 September 2019

Edited by W. T. A. Harrison, University of Aberdeen, Scotland

‡ Additional correspondence author, e-mail: awang_normah@yahoo.com.

Keywords: crystal structure; organotin; dithiocarbamate; Hirshfeld surface analysis; computational chemistry.

CCDC reference: 1952056

Supporting information: this article has supporting information at journals.iucr.org/e

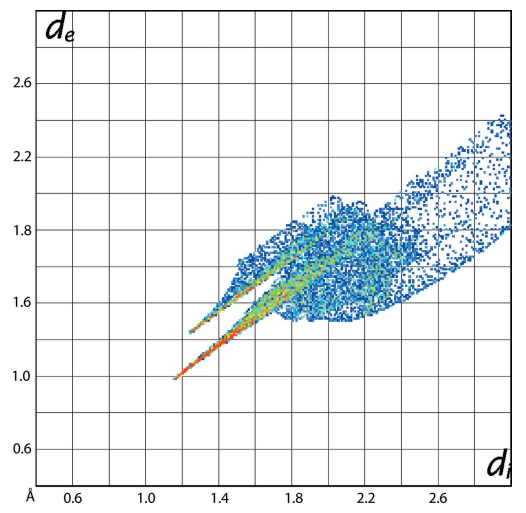

\section{(N,N-Diisopropyldithiocarbamato)triphenyltin(IV): crystal structure, Hirshfeld surface analysis and computational study}

\author{
Farah Natasha Haezam, ${ }^{a}$ Normah Awang, ${ }^{a} \ddagger$ Nurul Farahana Kamaludin, ${ }^{a}$ \\ Mukesh M. Jotani ${ }^{\mathrm{b}}$ and Edward R. T. Tiekink ${ }^{\mathrm{C} *}$
}

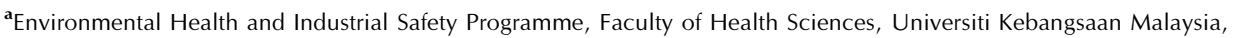
Jalan Raja Muda Abdul Aziz, 50300 Kuala Lumpur, Malaysia, 'Department of Physics, Bhavan's Sheth R. A. College of Science, Ahmedabad, Gujarat 380001, India, and ${ }^{\mathbf{c}}$ Research Centre for Crystalline Materials, School of Science and Technology, Sunway University, 47500 Bandar Sunway, Selangor Darul Ehsan, Malaysia. *Correspondence e-mail: edwardt@sunway.edu.my

The crystal and molecular structures of the title triorganotin dithiocarbamate, $\left[\mathrm{Sn}\left(\mathrm{C}_{6} \mathrm{H}_{5}\right)_{3}\left(\mathrm{C}_{7} \mathrm{H}_{14} \mathrm{NS}_{2}\right)\right]$, are described. The molecular geometry about the metal atom is highly distorted being based on a $\mathrm{C}_{3} \mathrm{~S}$ tetrahedron as the dithiocarbamate ligand is asymmetrically chelating to the tin centre. The close approach of the second thione-S atom [Sn ..S $=2.9264(4) \AA$ ] is largely responsible for the distortion. The molecular packing is almost devoid of directional interactions with only weak phenyl-C-H. $\mathrm{C}$ (phenyl) interactions, leading to centrosymmetric dimeric aggregates, being noted. An analysis of the calculated Hirshfeld surface points to the significance of $\mathrm{H} \cdot \mathrm{H}$ contacts, which contribute $66.6 \%$ of all contacts to the surface, with $\mathrm{C} \cdots \mathrm{H} / \mathrm{H} \cdots \mathrm{C}[26.8 \%]$ and $\mathrm{S} \cdots \mathrm{H} / \mathrm{H} \cdots \mathrm{H}[6.6 \%]$ contacts making up the balance.

\section{Chemical context}

Organotin(IV) compounds have long been investigated as potential anti-cancer agents (Gielen \& Tiekink, 2005) and studies in this area continue. Further, organotin compounds have received much attention owing to their potential therapeutic potential as anti-fungal, anti-bacterial, anti-malarial and schizonticidal agents (Khan et al., 2014). Metal dithiocarbamates have also encouraged much interest in the context of chemotherapeutic agents (Hogarth, 2012) and these include organotin(IV) dithiocarbamate compounds (Tiekink, 2008; Adeyemi \& Onwudiwe, 2018). In view of the wide-range of applications/potential of organotin(IV) dithiocarbamate compounds and in continuation of on-going studies in this area (Khan et al., 2015; Mohamad et al. 2016, 2017, 2018), the title compound, $\mathrm{Ph}_{3} \mathrm{Sn}\left[\mathrm{S}_{2} \mathrm{CN}(i-\mathrm{Pr})_{2}\right]$, (I), was synthesized and characterized spectroscopically. Herein, the crystal and molecular structures of (I) are described along with a detailed analysis of the molecular packing via the calculated Hirshfeld surfaces and computational chemistry study.

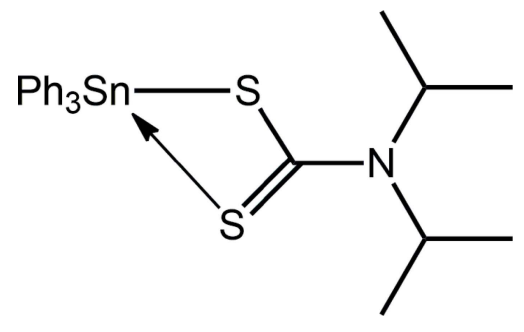


Table 1

Selected bond lengths $(\AA)$.

\begin{tabular}{llll}
\hline $\mathrm{Sn}-\mathrm{S} 1$ & $2.4792(4)$ & $\mathrm{C} 1-\mathrm{S} 1$ & $1.7587(15)$ \\
$\mathrm{Sn}-\mathrm{S} 2$ & $2.9264(4)$ & $\mathrm{C} 1-\mathrm{S} 2$ & $1.7006(16)$ \\
$\mathrm{Sn}-\mathrm{C} 11$ & $2.1446(14)$ & $\mathrm{C} 1-\mathrm{N} 1$ & $1.336(2)$ \\
$\mathrm{Sn}-\mathrm{C} 21$ & $2.1349(15)$ & $\mathrm{C} 5-\mathrm{N} 1$ & $1.495(2)$ \\
$\mathrm{Sn}-\mathrm{C} 31$ & $2.1754(15)$ & $\mathrm{C} 2-\mathrm{N} 1$ & $1.497(2)$ \\
\hline
\end{tabular}

\section{Structural commentary}

The tin atom in (I), Fig. 1, is coordinated by an asymmetrically bound dithiocarbamate ligand and three ipso-carbon atoms of the phenyl groups (Table 1). The disparity in the $\mathrm{Sn}-\mathrm{S}$ separations, i.e. $\Delta(\mathrm{Sn}-\mathrm{S})=\left[\left(\mathrm{Sn}-\mathrm{S}_{1}\right)-\left(\mathrm{Sn}-\mathrm{S}_{\mathrm{s}}\right)\right]=0.45 \AA$ $(1=$ long, $\mathrm{s}=$ short $)$, is rather great suggesting that the $\mathrm{Sn} \cdots \mathrm{S} 2$ interaction is weak. This is supported in the pattern of $\mathrm{C}-\mathrm{S}$ bond lengths with that involving the more tightly bound S1 atom being nearly $0.06 \AA$ longer than the equivalent bond with the weakly bound S2 atom. Despite this, a clear influence of the $\mathrm{S} 2$ atom is noted on the $\mathrm{Sn}-\mathrm{C}$ bond lengths with the $\mathrm{Sn}-\mathrm{C} 31$ bond length being significantly longer than the other $\mathrm{Sn}-\mathrm{C}$ bonds, Table 1 . The $\mathrm{S} 2-\mathrm{Sn}-\mathrm{C} 31$ bond angle is $158.41(4)^{\circ}$ and is suggestive of a trans-influence exerted by the S2 atom; there is no other trans angle about the tin atom. If the coordination geometry is considered as tetrahedral, the range of tetrahedral angles is $93.24(4)^{\circ}$, for $\mathrm{S} 1-\mathrm{Sn}-\mathrm{C} 31$, to $119.87(6)^{\circ}$, for $\mathrm{C} 11-\mathrm{Sn}-\mathrm{C} 21$. The range of angles assuming a five-coordinate, $\mathrm{C}_{3} \mathrm{~S}_{2}$, geometry is $65.260(11)^{\circ}$, for the $\mathrm{S} 1-$ $\mathrm{Sn}-\mathrm{S} 2$ chelate angle to the aforementioned $158.41(4)^{\circ}$. A descriptor for assigning coordination geometries to fivecoordinate species is $\tau$ (Addison et al., 1984). In the case of (I), this computes to 0.64 , which indicates a geometry somewhat closer to an ideal trigonal bipyramid $(\tau=1.0)$ than to an ideal square pyramid $(\tau=0.0)$. Also included in Table 1 are the $\mathrm{C}-$ $\mathrm{N}$ bond lengths, which show $\mathrm{C} 1-\mathrm{N} 1$ to be significantly shorter than the $\mathrm{C} 2-\mathrm{N} 1$ and $\mathrm{C} 5-\mathrm{N} 1$ bond lengths, an observation

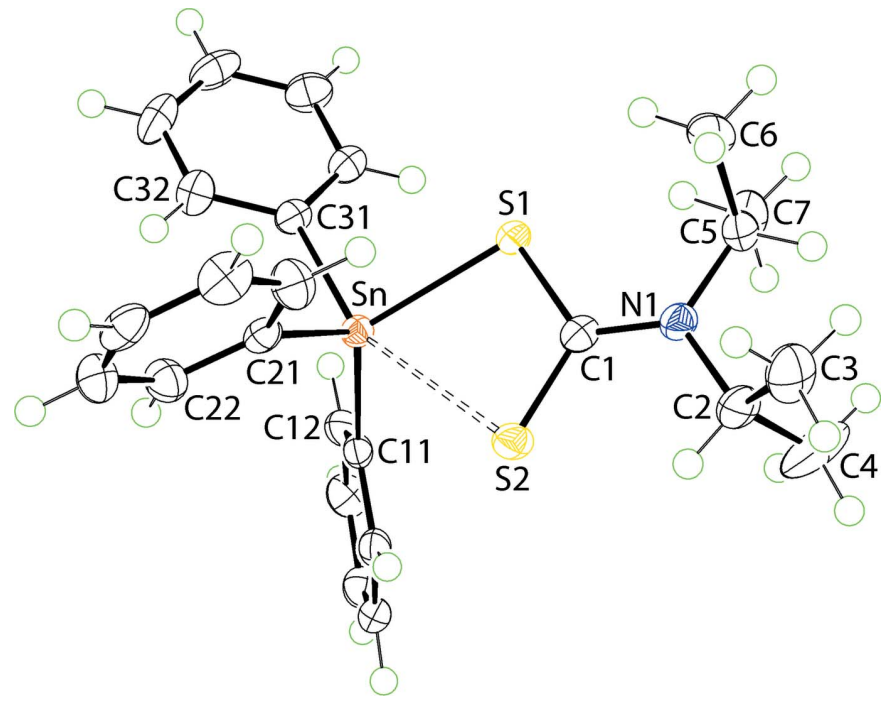

Figure 1

The molecular structure of (I) showing the atom-labelling scheme and displacement ellipsoids at the $70 \%$ probability level. The long Sn1 $\cdots$ S2 contact is indicated by a double-dashed line.
Table 2

Hydrogen-bond geometry $\left(\AA,^{\circ}\right)$.

\begin{tabular}{lllll}
\hline$D-\mathrm{H} \cdots A$ & $D-\mathrm{H}$ & $\mathrm{H} \cdots A$ & $D \cdots A$ & $D-\mathrm{H} \cdots A$ \\
\hline $\mathrm{C} 34-\mathrm{H} 34 \cdots \mathrm{C} 24^{\mathrm{i}}$ & 0.95 & 2.82 & $3.757(3)$ & 171 \\
\hline
\end{tabular}

Symmetry code: (i) $-x+1,-y,-z$

consistent with a significant contribution of the ${ }^{2-} \mathrm{S}_{2} \mathrm{C}=\mathrm{N}^{+}(i-$ $\mathrm{Pr})_{2}$ canonical form to the overall electronic structure of the dithiocarbamate ligand.

\section{Supramolecular features}

The geometric parameters characterizing the identified intermolecular interaction operating in the crystal of (I) are collated in Table 2. A phenyl-C-H..C (phenyl) contact less than the sum of the sum of the Waals radii (Spek, 2009) is noted to occur between centrosymmetrically related molecules, Fig. 2(a). This is an example of a localized $\mathrm{C}-\mathrm{H} \cdots \pi$ contact whereby the hydrogen atom directed towards a single carbon atom of the ring as opposed to a delocalized interaction where the hydrogen atom (or halide atom or lone-pair of electrons) is directed towards the centroid of the ring (Schollmeyer et al., 2008; Tiekink, 2017).

(a)

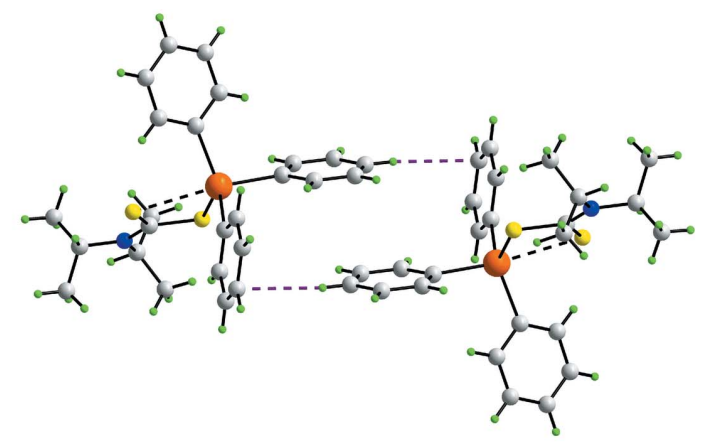

(b)

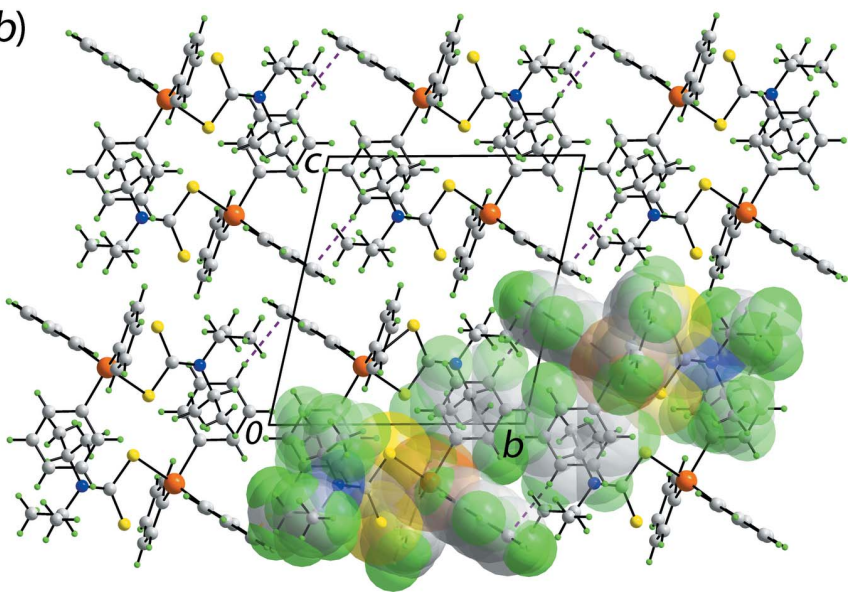

Figure 2

Molecular packing in the crystal of (I): (a) supramolecular dimer sustained by localized phenyl-C $-\mathrm{H} \cdots \mathrm{C}$ (phenyl) interactions shown as purple dashed lines and $(b)$ a view of the unit-cell contents in projection down the $a$ axis. One column of dimeric aggregates is highlighted in space-filling mode. 
Table 3

Summary of short interatomic contacts $(\AA)$ in (I).

The interatomic distances are calculated in Crystal Explorer 17 (Turner et al., 2017) whereby the $X-\mathrm{H}$ bond lengths are adjusted to their neutron values.

\begin{tabular}{lll}
\hline Contact & Distance & Symmetry operation \\
\hline $\mathrm{H} 7 A \cdots \mathrm{H} 12$ & 2.09 & $1-x, 1-y,-z$ \\
$\mathrm{H} 13 \cdots \mathrm{H} 26$ & 2.26 & $1+x, y, z$ \\
$\mathrm{C} 12 \cdots \mathrm{H} 36$ & 2.65 & $1-x, 1-y,-z$ \\
$\mathrm{C} 13 \cdots \mathrm{H} 26$ & 2.68 & $1+x, y, z$ \\
$\mathrm{C} 16 \cdots \mathrm{H} 23$ & 2.65 & $1-x,-y, 1-z$ \\
$\mathrm{C} 24 \cdots \mathrm{H} 34$ & 2.68 & $1-x,-y-z$ \\
\hline
\end{tabular}

\section{Hirshfeld surface analysis}

The Hirshfeld surface calculations for (I) were performed employing Crystal Explorer 17 (Turner et al., 2017) and recently published protocols (Tan et al., 2019). In the absence of classical hydrogen bonds, the influence of the localized C$\mathrm{H} \cdots \pi$ interaction, Table 2, as well as interatomic $\mathrm{H} \cdots \mathrm{H}$ and $\mathrm{C} \cdots \mathrm{H} / \mathrm{H} \cdots \mathrm{C}$ contacts, Table 3 , upon the molecular packing are evident as the diminutive-red spots near the participating carbon and hydrogen atoms on the Hirshfeld surfaces mapped over $d_{\text {norm }}$ in Fig. 3. It is also noted that with the exception of the methyl-H7 $A$ atom, all of the specified interatomic contacts only involve the carbon and hydrogen atoms of the coordinated phenyl rings, Table 3. On the Hirshfeld surface mapped over electrostatic potential in Fig. 4, the light-blue and faint-

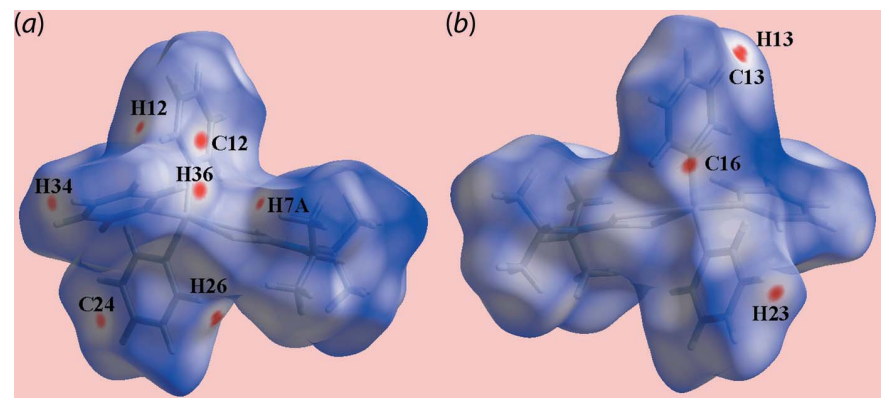

Figure 3

Two views of Hirshfeld surface for (I) mapped over $d_{\text {norm }}$ in the range -0.085 to +1.355 (arbitrary units), highlighting short interatomic $\mathrm{H} \cdots \mathrm{H}$ and $\mathrm{C} \cdots \mathrm{H} / \mathrm{H} \cdots \mathrm{C}$ contacts as diminutive red spots near the respective atoms.

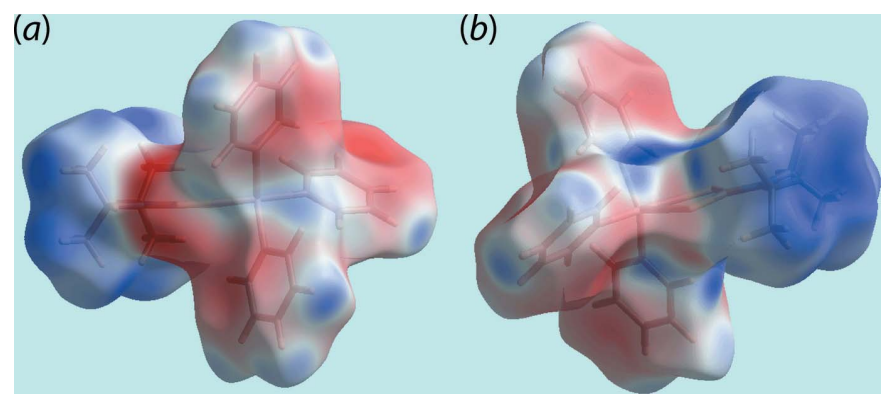

Figure 4

Two views of Hirshfeld surface mapped over the electrostatic potential (the red and blue regions represent negative and positive electrostatic potentials, respectively) in the range -0.032 to +0.035 atomic units.
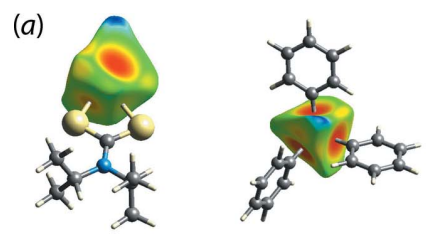

(b)
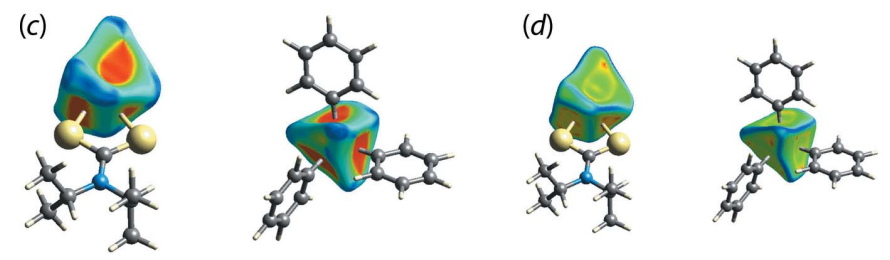

Figure 5

The Hirshfeld surfaces of the tin centre in (I) highlighting the coordination by the dithiocarbamate ligand (left-hand images) and the phenyl rings (right-hand images) mapped over $(a)$ the distance, $d_{\mathrm{e}}$, external to the surface in the range -0.981 to $2.436 \AA,(b) d_{\text {norm }}$ in the range -0.890 to $+1.135 \AA$, (c) the shape-index (S) from -1.0 to +1.0 (arbitrary units) and $(d)$ curvedness (C) from -4.0 to +0.4 (arbitrary units).

red regions, corresponding to positive and negative electrostatic potential, respectively, occur about the di-iso-propyl and triphenyltin groups, respectively.

As reported recently (Pinto et al., 2019), in addition to analysing the nature and strength of intermolecular interactions among molecules, the analyses of Hirshfeld surfaces can also provide useful insight into metal-ligand/donor atom interactions in coordination compounds. Thus, the distance from the surface to the nearest external $\left(d_{\mathrm{e}}\right)$ and internal $\left(d_{\mathrm{i}}\right)$ nuclei, the shape-index $(S)$ and the curvedness $(C)$ can also be plotted. Accordingly, Fig. 5 illustrates the Hirshfeld surfaces for the tin atom coordinated by dithiocarbamate ligand as well as by the three phenyl groups. The close proximity of the dithiocarbamate-S1 and phenyl-C11, C21 and C31 atoms to the tin centre are characterized as bright-red regions perpendicular to bond directions on the Hirshfeld surfaces mapped over $d_{\mathrm{e}}$, Fig. 5(a), and $d_{\text {norm }}$, Fig. 5(b), whereas the comparatively weak $\mathrm{Sn}-\mathrm{S} 2$ interaction appears as the faintred region. The longer $\mathrm{Sn}-\mathrm{C} 31$ bond compared to other two $\mathrm{Sn}-\mathrm{C}$ bonds, Table 1 , is also characterized from these Hirshfeld surfaces through the curvature of the red region. The $\mathrm{Sn}-\mathrm{S} 1$ and $\mathrm{Sn}-\mathrm{C}$ bonds result in the large red regions on the shape-index mapping in Fig. 5(c) compared to a small red region for the $\mathrm{Sn}-\mathrm{S} 2$ bond. On the Hirshfeld surfaces mapped over curvedness in Fig. 5(d), the strength of the tinligand bonds are characterized as the yellow areas separated by green regions. The coordination bonds for tin are also rationalized in the fingerprint plot taking into account only the Hirshfeld surface about the metal atom, Fig. 6 . The distribution of green points having upper short spike at $d_{\mathrm{e}}+d_{\mathrm{i}} \sim 2.4 \AA$ and the lower, long red spike at $d_{\mathrm{e}}+d_{\mathrm{i}} \sim 2.1 \AA$ are the result of the $\mathrm{Sn}-\mathrm{S}$ and $\mathrm{Sn}-\mathrm{C}$ bonds, respectively. This asymmetric distribution of points about the diagonal lacking homogeneity in colouration is due to the distorted coordination geometry about the tin atom. 


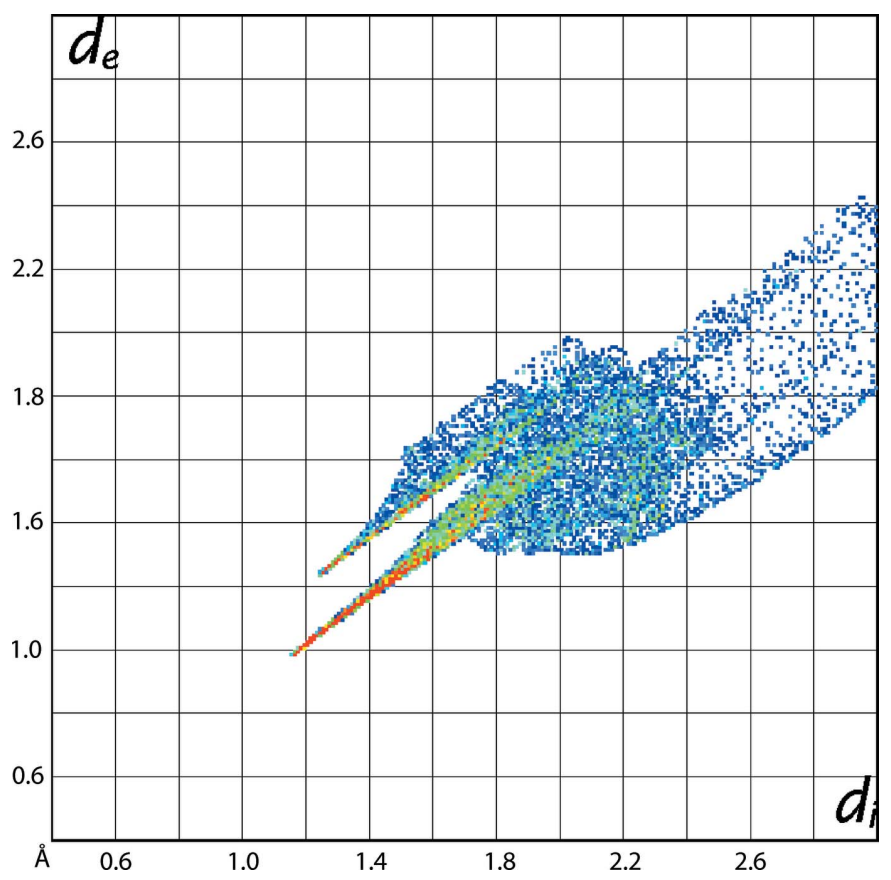

Figure 6

The fingerprint plot taking into account only the Hirshfeld surface about the tin atom.

It is clear from the the calculation of the overall twodimensional fingerprint plot for (I), Fig. 7(a), that the plot is asymmetric about the $\left(d_{\mathrm{e}}, d_{\mathrm{i}}\right)$ diagonal in the longer distance regions and have contributions only from the interatomic contacts involving carbon, hydrogen and sulfur atoms, Table 4. The two-dimensional fingerprint plots delineated into $\mathrm{H} \cdots \mathrm{H}$, C $\cdots \mathrm{H} / \mathrm{H} \cdots \mathrm{C}, \mathrm{C} \cdots \mathrm{C}$ and $\mathrm{S} \cdots \mathrm{H} / \mathrm{H} \cdots \mathrm{S}$ contacts are shown in Fig. $7(b)-(d)$, respectively. In the fingerprint plot delineated into $\mathrm{H} \cdots \mathrm{H}$ contacts in Fig. $7(b)$, the presence of the short interatomic $\mathrm{H} \cdots \mathrm{H}$ interaction involving the methyl-H7 $A$ and phenyl-H12 atoms is evident as the pair of short overlapping peaks at $d_{\mathrm{e}}+d_{\mathrm{i}} \sim 2.1 \AA$ with the other short interatomic $\mathrm{H} \cdots \mathrm{H}$ contact (Table 3) merged within the plot. The intermolecular $\mathrm{C}-\mathrm{H} \cdots \mathrm{C}$ interactions describing the localized $\mathrm{C}-\mathrm{H} \cdots \pi$ contacts are evidenced by a pronounced pair of characteristic wings around $\left(d_{\mathrm{e}}, d_{\mathrm{i}}\right) \sim(1.2 \AA, 1.8 \AA)$ and $\sim(1.8 \AA, 1.2 \AA)$ in

(a)

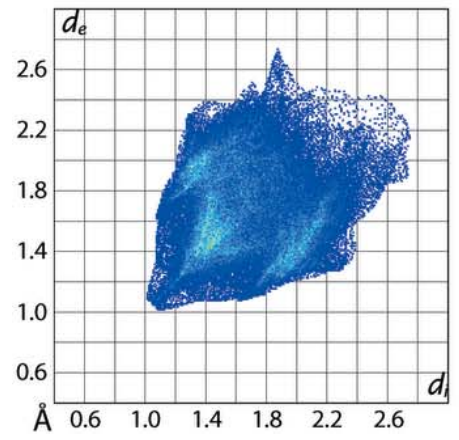

(b)

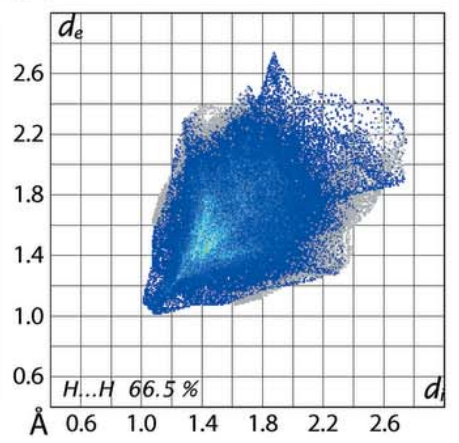

Table 4

Percentage contributions of interatomic contacts to the Hirshfeld surface for (I).

\begin{tabular}{ll}
\hline Contact & Percentage contribution \\
\hline $\mathrm{H} \cdots \mathrm{H}$ & 66.5 \\
$\mathrm{C} \cdots \mathrm{H} / \mathrm{H} \cdots \mathrm{C}$ & 26.8 \\
$\mathrm{~S} \cdots \mathrm{H} / \mathrm{H} \cdots \mathrm{S}$ & 6.6 \\
$\mathrm{C} \cdots \mathrm{S} / \mathrm{S} \cdots \mathrm{C}$ & 0.1 \\
\hline
\end{tabular}

Table 5

Summary of interaction energies $\left(\mathrm{kJ} \mathrm{mol}^{-1}\right)$ calculated for (I).

\begin{tabular}{lllllll}
\hline Contact & $R(\AA)$ & $E_{\text {ele }}$ & $E_{\text {pol }}$ & $E_{\text {dis }}$ & $E_{\text {rep }}$ & $E_{\text {tot }}$ \\
\hline $\mathrm{H} 7 A \cdots \mathrm{H} 12^{\mathrm{i}}+$ & 6.30 & & & & & \\
$\mathrm{H} 36 \cdots \mathrm{C} 12^{\mathrm{i}}$ & & -17.5 & -7.0 & -112.7 & 68.0 & -68.8 \\
$\mathrm{H} 13 \cdots \mathrm{H} 26^{\mathrm{ii}}+$ & 9.76 & & & & & \\
$\mathrm{C} 13 \cdots \mathrm{H} 26^{\mathrm{ii}}$ & & -8.7 & -2.0 & -31.6 & 18.0 & -24.0 \\
$\mathrm{C} 16 \cdots \mathrm{H} 23^{\mathrm{iii}}$ & 9.46 & -12.9 & -2.0 & -41.9 & 29.5 & -28.2 \\
$\mathrm{C} 24 \cdots \mathrm{H} 34^{\mathrm{iv}}$ & 10.62 & -11.0 & -2.8 & -33.8 & 21.6 & -26.0 \\
\hline
\end{tabular}

Notes: Symmetry operations: (i) $1-x, 1-y,-z$; (ii) $1+x, y, z$; (iii) $1-x,-y, 1-z$; (iv) $1-x,-y,-z$.

the fingerprint plot delineated into $\mathrm{C} \cdots \mathrm{H} / \mathrm{H} \cdots \mathrm{C}$ contacts shown in Fig. 7(c). The other short interatomic C $\cdots \mathrm{H}$ contacts summarized in Table 3 appear as the pair of forceps-like tips at $d_{\mathrm{e}}+d_{\mathrm{i}} \sim 2.7 \AA$. The fingerprint plot delineated into $\mathrm{S} \cdots \mathrm{H} /$ $\mathrm{H}$...S contacts in Fig. $7(d)$ indicate that sulfur atoms are nearly at van der Waals separation from the symmetry-related hydrogen atoms.

\section{Computational chemistry}

The pairwise interaction energies between the molecules within the crystal were calculated using Crystal Explorer 17 (Turner et al., 2017) and summing up the four energy components: electrostatic $\left(E_{\text {ele }}\right)$, polarization $\left(E_{\mathrm{pol}}\right)$, dispersion $\left(E_{\mathrm{dis}}\right)$ and exchange-repulsion $\left(E_{\mathrm{rep}}\right)$. The energies were obtained using the wave function calculated at the HF/STO$3 \mathrm{G}$ level of theory. The strength and the nature of intermolecular interactions in terms of their energies are summarized in Table 5. An analysis of these reveals that the dispersion energy component makes the greatest contribution

(c)

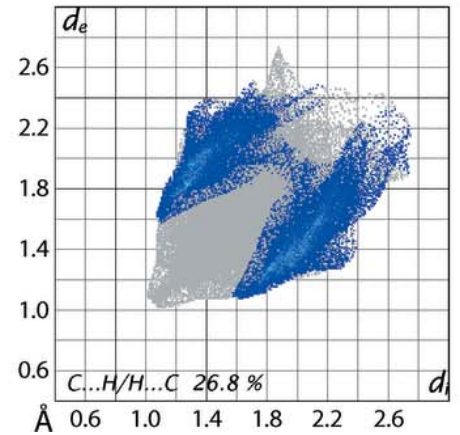

(d)

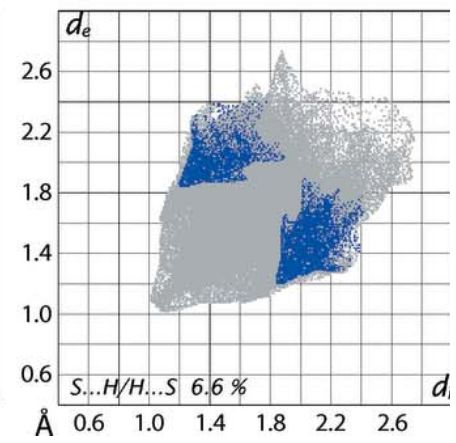

Figure 7

(a) A comparison of the full two-dimensional fingerprint plot for (I) and those delineated into $(b) \mathrm{H} \cdots \mathrm{H},(c) \mathrm{C} \cdots \mathrm{H} / \mathrm{H} \cdots \mathrm{C}$ and $(d) \mathrm{S} \cdots \mathrm{H} / \mathrm{H} \cdots \mathrm{S}$ contacts. 

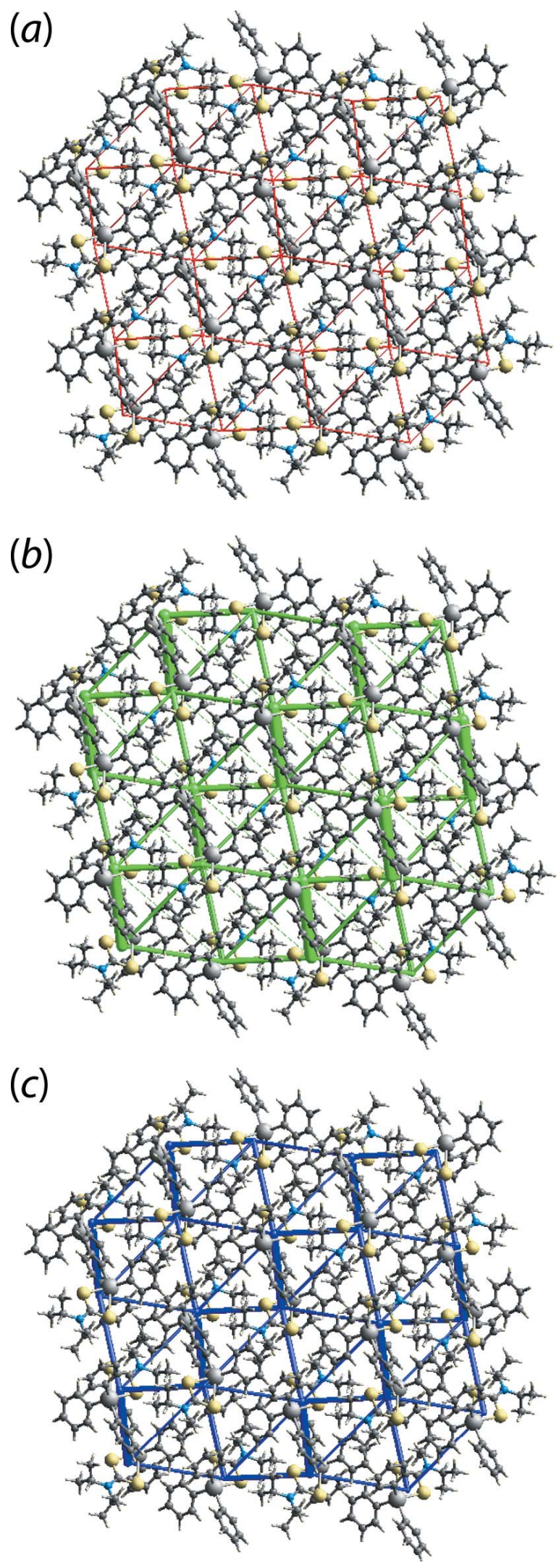

Figure 8

The energy frameworks calculated for (I) viewed down the $c$-axis direction showing the $(a)$ electrostatic potential force, $(b)$ dispersion force and $(c)$ total energy. The energy frameworks were adjusted to the same scale factor of 30 with a cut-off value of $3 \mathrm{~kJ} \mathrm{~mol}^{-1}$ within $2 \times 2 \times 2$ unit cells. to the energies in the absence of classical hydrogen (electrostatic) bonds. Among the short interatomic contacts listed in Table 5, the intermolecular phenyl-C-H36 ‥C12 contact

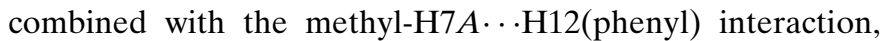
occurring between the same pair of symmetry-related molecules, gives rise to the maximum total energy of interaction, compared to the other interactions, which have almost the same energy values.

The graphical representation of the magnitudes of intermolecular energies in Fig. 8, i.e. energy frameworks, relies on a red, green and blue colour code scheme, reflecting the $E_{\text {ele }}$, $E_{\text {disp }}$ and $E_{\text {tot }}$ components, respectively. For the direct comparison of magnitudes of interaction energies, their magnitudes were adjusted to same scale factor of 30 with a cutoff value of $3 \mathrm{~kJ} \mathrm{~mol}^{-1}$ within $2 \times 2 \times 2$ unit cells. It is clear from Fig. 8 that the green cylinders joining the centroids of molecular pairs highlighting the dispersion components make a significant contribution to the supramolecular architecture in the crystal.

\section{Database survey}

As indicated in a recent report (Mohamad et al., 2018), there are nearly 50 crystal structures available for molecules of the general formula $\mathrm{Ph}_{3} \mathrm{Sn}\left(\mathrm{S}_{2} \mathrm{CN} R R^{\prime}\right)$ and, with a number of these having multiple molecules in the asymmetric unit, there are almost 60 independent molecules. These conform to the same structural motif. An analysis of the key geometric parameters defining the mode of coordination of the dithiocarbamate ligands showed that there were no systematic variations that could be correlated with the nature of the dithiocarbamate ligand, i.e. $R / R^{\prime}$ substituents. This observation is borne out by DFT calculations on different organotin systems that proved the influence of molecular packing on (non-systematic) geometric parameters, including metal-sulfur/halide bonds (Buntine et al., 1998a,b, 1999). In terms of $\mathrm{Ph}_{3} \mathrm{Sn}\left(\mathrm{S}_{2} \mathrm{CN} R R^{\prime}\right)$, the mean $\mathrm{Sn}-\mathrm{S}_{\mathrm{s}}$ bond length is $2.47 \AA$ (standard deviation = $0.013 \AA$ ) and the average $\mathrm{Sn}-\mathrm{S}_{1}$ bond length is $3.04 \AA$ $(0.070 \AA)$. The $\mathrm{Sn}-\mathrm{S}_{\mathrm{s}}$ and $\mathrm{Sn}-\mathrm{S}_{1}$ bond lengths in (I) both fall within $2 \sigma$ of their respective means.

The homogeneity in the molecular structures of $\mathrm{Ph}_{3} \mathrm{Sn}\left(\mathrm{S}_{2} \mathrm{CN} R R^{\prime}\right)$ is quite remarkable. Structural diversity is well-established for the organotin dithiocarbamates (Tiekink, 2008; Muthalib et al., 2014) such as for molecules of the general formula $R^{\prime \prime}{ }_{2} \mathrm{Sn}\left(\mathrm{S}_{2} \mathrm{CN} R R^{\prime}\right)_{2}$, for which four distinct structural motifs are known (Zaldi et al., 2017). Also, the behaviour of triphenyltin dithiocarbamates contrasts the analogous chemistry of triphenyltin carboxylates (Tiekink, 1991). These are often monomeric (e.g. Basu Baul et al., 2001), as for (I), but, polymeric examples are known (e.g. Willem et al., 1997; Smyth \& Tiekink, 2000). The polymeric structures occur when the carboxylate ligands are bidentate bridging, leading to trans $-\mathrm{C}_{3} \mathrm{O}_{2}$ trigonal-bipyramidal coordination geometries for the tin atoms. This fundamental difference in structural chemistry arises as a result of the significant contribution of the ${ }^{2-} \mathrm{S}_{2} \mathrm{C}=\mathrm{N}^{+} R R^{\prime}$ canonical form to the electronic structure of the dithiocarbamate anion, as discussed 
Table 6

Experimental details.

\begin{tabular}{|c|c|}
\hline \multicolumn{2}{|l|}{ Crystal data } \\
\hline Chemical formula & {$\left[\mathrm{Sn}\left(\mathrm{C}_{6} \mathrm{H}_{5}\right)_{3}\left(\mathrm{C}_{7} \mathrm{H}_{14} \mathrm{NS}_{2}\right)\right]$} \\
\hline$M_{\mathrm{r}}$ & 526.30 \\
\hline Crystal system, space group & Triclinic, $P \overline{1}$ \\
\hline Temperature (K) & 100 \\
\hline$a, b, c(\AA)$ & $9.7572(1), 11.7030(2), 11.7602(2)$ \\
\hline$\alpha, \beta, \gamma\left({ }^{\circ}\right)$ & 74.419 (1), 80.114 (1), 67.285 (2) \\
\hline$V\left(\AA^{3}\right)$ & $1189.71(4)$ \\
\hline$Z$ & 2 \\
\hline Radiation type & $\mathrm{Cu} \mathrm{K \alpha}$ \\
\hline$\mu\left(\mathrm{mm}^{-1}\right)$ & 10.25 \\
\hline Crystal size $(\mathrm{mm})$ & $0.12 \times 0.11 \times 0.08$ \\
\hline \multicolumn{2}{|l|}{ Data collection } \\
\hline Diffractometer & $\begin{array}{l}\text { Rigaku XtaLAB Synergy Dualflex } \\
\text { AtlasS2 }\end{array}$ \\
\hline Absorption correction & $\begin{array}{l}\text { Gaussian (CrysAlis PRO; Rigaku } \\
\quad \text { OD, 2018) }\end{array}$ \\
\hline$T_{\min }, T_{\max }$ & $0.840,1.000$ \\
\hline $\begin{array}{l}\text { No. of measured, independent and } \\
\text { observed }[I>2 \sigma(I)] \text { reflections }\end{array}$ & $28219,4248,4231$ \\
\hline$R_{\text {int }}$ & 0.022 \\
\hline$(\sin \theta / \lambda)_{\max }\left(\AA^{-1}\right)$ & 0.597 \\
\hline \multicolumn{2}{|l|}{ Refinement } \\
\hline$R\left[F^{2}>2 \sigma\left(F^{2}\right)\right], w R\left(F^{2}\right), S$ & $0.015,0.040,1.00$ \\
\hline No. of reflections & 4248 \\
\hline No. of parameters & 266 \\
\hline H-atom treatment & $\mathrm{H}$-atom parameters constrained \\
\hline$\Delta \rho_{\max }, \Delta \rho_{\min }\left(\mathrm{e} \AA^{-3}\right)$ & $0.36,-0.44$ \\
\hline
\end{tabular}

Computer programs: CrysAlis PRO (Rigaku OD, 2018), SHELXS (Sheldrick, 2015a), SHELXL2014 (Sheldrick, 2015b), ORTEP-3 for Windows (Farrugia, 2012), DIAMOND (Brandenburg, 2006) and publCIF (Westrip, 2010).

above. The formal negative charge on each sulfur atom makes this ligand a very efficient chelator which effectively reduces the Lewis acidity of the tin centre. Far from being a curiosity, such behaviour, i.e. dithiocarbamate ligands reducing the Lewis acidity of metal centres, when compared to related xanthate $\left({ }^{-} \mathrm{S}_{2} \mathrm{COR}\right)$ and dithiophopshate $\left[\left({ }^{-} \mathrm{S}_{2} \mathrm{P}(\mathrm{O} R)_{2}\right]\right.$ ligands, leads to stark differences in coordination propensities in zinc-triad element 1,1-dithiolate compounds, as has been reviewed recently (Tiekink, 2018a,b).

\section{Synthesis and crystallization}

All chemicals and solvents were used as purchased without purification. The melting point was determined using an automated melting point apparatus (MPA 120 EZ-Melt). Carbon, hydrogen, nitrogen and sulfur analyses were performed on a Leco CHNS-932 Elemental Analyzer.

Di-iso-propylamine (Aldrich; $1.41 \mathrm{ml}, 10 \mathrm{mmol}$ ) dissolved in ethanol $(30 \mathrm{ml})$ was stirred under ice-bath conditions at $277 \mathrm{~K}$ for 20 mins. A $25 \%$ ammonia solution (1-2 ml) was added to provide basic conditions. Then, a cold ethanolic solution of carbon disulfide $(0.60 \mathrm{ml}, 10 \mathrm{mmol})$ was added dropwise into the solution followed by stirring for $2 \mathrm{~h}$. After that, triphenyltin(IV) chloride (Merck; $3.85 \mathrm{~g}, 10 \mathrm{mmol}$ ) dissolved in ethanol $(20-30 \mathrm{ml})$ was added dropwise into the solution followed by further stirring for $2 \mathrm{~h}$. The precipitate that formed was filtered and washed a few times with cold ethanol to remove impurities. Finally, the colourless precipi- tate was dried in a desiccator. Recrystallization was carried out by dissolving the compound in a chloroform and ethanol mixture $(1: 1 v / v)$. This solution was allowed to slowly evaporate at room temperature yielding colourless slabs of (I). Yield: 47\%, m. p.: 437.8-440.2 K. Elemental analysis: Calculated (\%): C 57.07, H 5.51, N 2.66, S 12.19. Found (\%): C 57.39, H 5.31, N 2.48, S 11.26.

\section{Refinement}

Crystal data, data collection and structure refinement details are summarized in Table 6. Carbon-bound $\mathrm{H}$ atoms were placed in calculated positions $(\mathrm{C}-\mathrm{H}=0.95-1.00 \AA)$ and were included in the refinement in the riding model approximation, with $U_{\text {iso }}(\mathrm{H})$ set to $1.2-1.5 U_{\text {eq }}(\mathrm{C})$.

\section{Acknowledgements}

We gratefully acknowledge the Faculty of Health Sciences and the Faculty of Science and Technology of the Universiti Kebangsaan Malaysia for providing essential laboratory facilities and for technical support from the laboratory assistants. The Universiti Malaysia Terengganu is thanked for the elemental analysis. The authors also thank the Research Centre of Crystalline Materials X-ray crystallography laboratory for the X-ray intensity data.

\section{Funding information}

This work was supported by the Fundamental Research Grant Scheme (FRGS/1/2018/STG01/UKM/02/20) awarded by the Ministry of Education (MOE). Crystallographic research at Sunway University is supported by Sunway University Sdn Bhd (grant No. STR-RCTR-RCCM-001-2019).

\section{References}

Addison, A. W., Rao, T. N., Reedijk, J., van Rijn, J. \& Verschoor, G. C. (1984). J. Chem. Soc. Dalton Trans. pp. 1349-1356.

Adeyemi, J. O. \& Onwudiwe, D. C. (2018). Molecules, 23 article No. 2571.

Basu Baul, T. S., Dhar, S., Pyke, S. M., Tiekink, E. R. T., Rivarola, E., Butcher, R. \& Smith, F. E. (2001). J. Organomet. Chem. 633, 717.

Brandenburg, K. (2006). DIAMOND. Crystal Impact GbR, Bonn, Germany.

Buntine, M. A., Hall, V. J., Kosovel, F. J. \& Tiekink, E. R. T. (1998a). J. Phys. Chem. A, 102, 2472-2482.

Buntine, M. A., Hall, V. J. \& Tiekink, E. R. T. (1998b). Z. Kristallogr. 213, 669-678.

Buntine, M. A., Hall, V. J. \& Tiekink, E. R. T. (1999). Z. Kristallogr. 214, 124-134.

Farrugia, L. J. (2012). J. Appl. Cryst. 45, 849-854.

Gielen, M. \& Tiekink, E. R. T. (2005). Metallotherapeutic drugs and metal-based diagnostic agents: the use of metals in medicine, edited by M. Gielen \& E. R. T. Tiekink, pp. 421-439. Chichester: John Wiley \& Sons Ltd.

Hogarth, G. (2012). Mini Rev. Med. Chem. 12, 1202-1215.

Khan, N., Farina, Y., Mun, L. K., Rajab, N. F. \& Awang, N. (2014). J. Mol. Struct. 1076, 403-410.

Khan, N., Farina, Y., Mun, L. K., Rajab, N. F. \& Awang, N. (2015). Polyhedron, 85, 754-760. 
Mohamad, R., Awang, N., Kamaludin, N. F. \& Abu Bakar, N. F. (2016). Res. J. Pharm. Biol. Chem. Sci. 7, 1269-1274.

Mohamad, R., Awang, N., Kamaludin, N. F., Jotani, M. M. \& Tiekink, E. R. T. (2017). Acta Cryst. E73, 260-265.

Mohamad, R., Awang, N., Kamaludin, N. F., Jotani, M. M. \& Tiekink, E. R. T. (2018). Acta Cryst. E74, 630-637.

Muthalib, A. F. A., Baba, I., Khaledi, H., Ali, H. M. \& Tiekink, E. R. T. (2014). Z. Kristallogr. 229, 39-46.

Pinto, C. B., Dos Santos, L. H. R. \& Rodrigues, B. L. (2019). Acta Cryst. C75, 707-716.

Rigaku OD (2018). CrysAlis PRO. Rigaku Oxford Diffraction Corporation, Yarnton, England.

Schollmeyer, D., Shishkin, O. V., Rühl, T. \& Vysotsky, M. O. (2008). CrystEngComm, 10, 715-723.

Sheldrick, G. M. (2015a). Acta Cryst. A71, 3-8.

Sheldrick, G. M. (2015b). Acta Cryst. C71, 3-8.

Smyth, D. R. \& Tiekink, E. R. T. (2000). Z. Kristallogr. New Cryst. Struct. 215, 81-82.
Spek, A. L. (2009). Acta Cryst. D65, 148-155.

Tan, S. L., Jotani, M. M. \& Tiekink, E. R. T. (2019). Acta Cryst. E75, 308-318.

Tiekink, E. R. T. (1991). Appl. Organomet. Chem. 5, 1-23.

Tiekink, E. R. T. (2008). Appl. Organomet. Chem. 22, 533-550.

Tiekink, E. R. T. (2017). Coord. Chem. Rev. 345, 209-228.

Tiekink, E. R. T. (2018a). Crystals, 8, article no. 292.

Tiekink, E. R. T. (2018b). Crystals, 8 , article no. 18.

Turner, M. J., Mckinnon, J. J., Wolff, S. K., Grimwood, D. J., Spackman, P. R., Jayatilaka, D. \& Spackman, M. A. (2017). Crystal Explorer 17. The University of Western Australia.

Westrip, S. P. (2010). J. Appl. Cryst. 43, 920-925.

Willem, R., Bouhdid, A., Mahieu, B., Ghys, L., Biesemans, M., Tiekink, E. R. T., de Vos, D. \& Gielen, M. (1997). J. Organomet. Chem. 531, 151-158.

Zaldi, N. B., Hussen, R. S. D., Lee, S. M., Halcovitch, N. R., Jotani, M. M. \& Tiekink, E. R. T. (2017). Acta Cryst. E73, 842-848. 


\section{supporting information}

Acta Cryst. (2019). E75, 1479-1485 [https://doi.org/10.1107/S2056989019012490]

\section{(N,N-Diisopropyldithiocarbamato)triphenyltin(IV): crystal structure, Hirshfeld surface analysis and computational study}

Farah Natasha Haezam, Normah Awang, Nurul Farahana Kamaludin, Mukesh M. Jotani and

\section{Edward R. T. Tiekink}

Computing details

Data collection: CrysAlis PRO (Rigaku OD, 2018); cell refinement: CrysAlis PRO (Rigaku OD, 2018); data reduction: CrysAlis PRO (Rigaku OD, 2018); program(s) used to solve structure: SHELXS (Sheldrick, 2015a); program(s) used to refine structure: SHELXL2014 (Sheldrick, 2015b); molecular graphics: ORTEP-3 for Windows (Farrugia, 2012) and DIAMOND (Brandenburg, 2006); software used to prepare material for publication: publCIF (Westrip, 2010).

(N,N-Diisopropyldithiocarbamato)triphenyltin(IV)

Crystal data

$\left[\mathrm{Sn}\left(\mathrm{C}_{6} \mathrm{H}_{5}\right)_{3}\left(\mathrm{C}_{7} \mathrm{H}_{14} \mathrm{NS}_{2}\right)\right]$

$M_{r}=526.30$

Triclinic, $P \overline{1}$

$a=9.7572(1) \AA$

$b=11.7030(2) \AA$

$c=11.7602(2) \AA$

$\alpha=74.419(1)^{\circ}$

$\beta=80.114(1)^{\circ}$

$\gamma=67.285(2)^{\circ}$

$V=1189.71(4) \AA^{3}$

\section{Data collection}

Rigaku XtaLAB Synergy Dualflex AtlasS2 diffractometer

Detector resolution: 5.2558 pixels $\mathrm{mm}^{-1}$ $\omega$ scans

Absorption correction: gaussian

(CrysAlis PRO; Rigaku OD, 2018)

$T_{\min }=0.840, T_{\max }=1.000$

28219 measured reflections

\section{Refinement}

Refinement on $F^{2}$

Least-squares matrix: full

$R\left[F^{2}>2 \sigma\left(F^{2}\right)\right]=0.015$

$w R\left(F^{2}\right)=0.040$

$S=1.00$

4248 reflections

266 parameters

0 restraints
$Z=2$

$F(000)=536$

$D_{\mathrm{x}}=1.469 \mathrm{Mg} \mathrm{m}^{-3}$

$\mathrm{Cu} K \alpha$ radiation, $\lambda=1.54184 \AA$

Cell parameters from 24601 reflections

$\theta=3.9-76.3^{\circ}$

$\mu=10.25 \mathrm{~mm}^{-1}$

$T=100 \mathrm{~K}$

Prism, colourless

$0.12 \times 0.11 \times 0.08 \mathrm{~mm}$

4248 independent reflections

4231 reflections with $I>2 \sigma(I)$

$R_{\text {int }}=0.022$

$\theta_{\text {max }}=67.1^{\circ}, \theta_{\min }=3.9^{\circ}$

$h=-11 \rightarrow 11$

$k=-13 \rightarrow 13$

$l=-13 \rightarrow 14$ 
$w=1 /\left[\sigma^{2}\left(F_{\mathrm{o}}^{2}\right)+(0.026 P)^{2}+0.5977 P\right]$

where $P=\left(F_{\mathrm{o}}^{2}+2 F_{\mathrm{c}}^{2}\right) / 3$

$(\Delta / \sigma)_{\max }=0.001$
$\Delta \rho_{\max }=0.36$ e $\AA^{-3}$
$\Delta \rho_{\min }=-0.44$ e $\AA^{-3}$

Special details

Geometry. All esds (except the esd in the dihedral angle between two 1.s. planes) are estimated using the full covariance matrix. The cell esds are taken into account individually in the estimation of esds in distances, angles and torsion angles; correlations between esds in cell parameters are only used when they are defined by crystal symmetry. An approximate (isotropic) treatment of cell esds is used for estimating esds involving l.s. planes.

Fractional atomic coordinates and isotropic or equivalent isotropic displacement parameters $\left(\hat{A}^{2}\right)$

\begin{tabular}{|c|c|c|c|c|}
\hline & $x$ & $y$ & $z$ & $U_{\text {iso }} * / U_{\text {eq }}$ \\
\hline $\mathrm{Sn}$ & $0.39008(2)$ & $0.31848(2)$ & $0.21713(2)$ & $0.01326(4)$ \\
\hline S1 & $0.19166(4)$ & $0.50402(3)$ & $0.11108(3)$ & $0.01639(8)$ \\
\hline $\mathrm{S} 2$ & $0.17439(4)$ & $0.47895(4)$ & $0.36811(3)$ & $0.01880(8)$ \\
\hline N1 & $-0.00996(14)$ & $0.67737(12)$ & $0.22420(12)$ & $0.0176(3)$ \\
\hline $\mathrm{C} 1$ & $0.10482(15)$ & $0.56682(14)$ & $0.23615(14)$ & $0.0157(3)$ \\
\hline $\mathrm{C} 2$ & $-0.08409(18)$ & 0.72965 (17) & $0.33124(16)$ & $0.0259(4)$ \\
\hline $\mathrm{H} 2$ & -0.0355 & 0.6655 & 0.4017 & $0.031 *$ \\
\hline $\mathrm{C} 3$ & $-0.24831(19)$ & $0.74782(18)$ & $0.34878(17)$ & $0.0301(4)$ \\
\hline $\mathrm{H} 3 \mathrm{~A}$ & -0.3009 & 0.8147 & 0.2840 & $0.045^{*}$ \\
\hline H3B & -0.2902 & 0.7723 & 0.4243 & $0.045^{*}$ \\
\hline $\mathrm{H} 3 \mathrm{C}$ & -0.2600 & 0.6682 & 0.3493 & $0.045^{*}$ \\
\hline $\mathrm{C} 4$ & $-0.0574(2)$ & $0.8507(2)$ & $0.3257(2)$ & $0.0454(5)$ \\
\hline $\mathrm{H} 4 \mathrm{~A}$ & 0.0498 & 0.8342 & 0.3141 & $0.068^{*}$ \\
\hline $\mathrm{H} 4 \mathrm{~B}$ & -0.0976 & 0.8788 & 0.3998 & $0.068 *$ \\
\hline $\mathrm{H} 4 \mathrm{C}$ & -0.1073 & 0.9170 & 0.2594 & $0.068 *$ \\
\hline $\mathrm{C} 5$ & $-0.07259(17)$ & $0.75964(14)$ & $0.11003(14)$ & $0.0196(3)$ \\
\hline H5 & -0.1546 & 0.8354 & 0.1323 & $0.023 *$ \\
\hline $\mathrm{C} 6$ & $-0.1481(2)$ & $0.69886(17)$ & $0.05404(17)$ & $0.0273(4)$ \\
\hline H6A & -0.2025 & 0.7616 & -0.0122 & $0.041^{*}$ \\
\hline H6B & -0.2180 & 0.6691 & 0.1132 & $0.041^{*}$ \\
\hline $\mathrm{H} 6 \mathrm{C}$ & -0.0727 & 0.6267 & 0.0250 & $0.041^{*}$ \\
\hline $\mathrm{C} 7$ & $0.03571(19)$ & $0.81240(16)$ & $0.02586(16)$ & $0.0278(4)$ \\
\hline $\mathrm{H} 7 \mathrm{~A}$ & 0.1147 & 0.7437 & -0.0056 & $0.042 *$ \\
\hline H7B & 0.0798 & 0.8497 & 0.0683 & $0.042 *$ \\
\hline $\mathrm{H} 7 \mathrm{C}$ & -0.0173 & 0.8779 & -0.0396 & $0.042 *$ \\
\hline C11 & $0.55885(16)$ & $0.34926(13)$ & $0.28704(13)$ & $0.0147(3)$ \\
\hline $\mathrm{C} 12$ & $0.68313(16)$ & $0.35637(15)$ & 0.21077 (14) & $0.0191(3)$ \\
\hline H12 & 0.6918 & 0.3435 & 0.1331 & $0.023 *$ \\
\hline $\mathrm{C} 13$ & $0.79426(17)$ & $0.38199(16)$ & $0.24707(15)$ & $0.0228(3)$ \\
\hline H13 & 0.8761 & 0.3902 & 0.1931 & $0.027^{*}$ \\
\hline C14 & $0.78624(17)$ & $0.39561(15)$ & $0.36188(16)$ & $0.0220(3)$ \\
\hline H14 & 0.8633 & 0.4115 & 0.3872 & $0.026^{*}$ \\
\hline $\mathrm{C} 15$ & $0.66454(17)$ & 0.38591 (14) & $0.43962(15)$ & $0.0195(3)$ \\
\hline H15 & 0.6594 & 0.3934 & 0.5188 & $0.023^{*}$ \\
\hline $\mathrm{C} 16$ & $0.55062(16)$ & 0.36527 (14) & 0.40185 (14) & $0.0167(3)$ \\
\hline H16 & 0.4661 & 0.3620 & 0.4546 & $0.020^{*}$ \\
\hline
\end{tabular}




$\begin{array}{lllll}\mathrm{C} 21 & 0.31244(16) & 0.16861(14) & 0.31013(13) & 0.0161(3) \\ \mathrm{C} 22 & 0.40747(18) & 0.05244(15) & 0.37020(15) & 0.0215(3) \\ \mathrm{H} 22 & 0.5088 & 0.0403 & 0.3739 & 0.026^{*} \\ \mathrm{C} 23 & 0.3558(2) & -0.04562(16) & 0.42466(16) & 0.0256(4) \\ \mathrm{H} 23 & 0.4216 & -0.1239 & 0.4661 & 0.031^{*} \\ \mathrm{C} 24 & 0.20910(19) & -0.03021(16) & 0.41896(15) & 0.0227(3) \\ \mathrm{H} 24 & 0.1740 & -0.0975 & 0.4565 & 0.027^{*} \\ \mathrm{C} 25 & 0.11378(18) & 0.08408(17) & 0.35814(16) & 0.0255(4) \\ \mathrm{H} 25 & 0.0132 & 0.0950 & 0.3529 & 0.031^{*} \\ \text { C26 } & 0.16529(18) & 0.18255(16) & 0.30497(15) & 0.0234(3) \\ \mathrm{H} 26 & 0.0989 & 0.2610 & 0.2643 & 0.028^{*} \\ \mathrm{C} 31 & 0.50078(15) & 0.25703(14) & 0.05537(14) & 0.0162(3) \\ \text { C32 } & 0.55917(18) & 0.12811(15) & 0.05353(16) & 0.0229(3) \\ \mathrm{H} 32 & 0.5551 & 0.0668 & 0.1246 & 0.027^{*} \\ \text { C33 } & 0.62313(19) & 0.08811(16) & -0.05083(17) & 0.0282(4) \\ \text { H33 } & 0.6622 & 0.0000 & -0.0505 & 0.034^{*} \\ \text { C34 } & 0.63013(19) & 0.17592(18) & -0.15492(16) & 0.0272(4) \\ \text { H34 } & 0.6732 & 0.1483 & -0.2262 & 0.033^{*} \\ \text { C35 } & 0.57407(19) & 0.30455(17) & -0.15524(15) & 0.0249(3) \\ \text { H35 } & 0.5790 & 0.3653 & -0.2265 & 0.030^{*} \\ \text { C36 } & 0.51064(17) & 0.34382(15) & -0.05060(14) & 0.0197(3) \\ \text { H36 } & 0.4731 & 0.4319 & -0.0512 & 0.024^{*}\end{array}$

Atomic displacement parameters $\left(\AA^{2}\right)$

\begin{tabular}{lllllll}
\hline & $U^{11}$ & $U^{22}$ & $U^{33}$ & $U^{12}$ & $U^{13}$ & $U^{23}$ \\
\hline Sn & $0.01301(6)$ & $0.01352(6)$ & $0.01339(6)$ & $-0.00463(4)$ & $-0.00068(4)$ & $-0.00360(4)$ \\
S1 & $0.01698(17)$ & $0.01653(17)$ & $0.01422(18)$ & $-0.00254(13)$ & $-0.00113(13)$ & $-0.00638(13)$ \\
S2 & $0.01615(17)$ & $0.02318(18)$ & $0.01490(18)$ & $-0.00338(14)$ & $-0.00031(13)$ & $-0.00680(14)$ \\
N1 & $0.0147(6)$ & $0.0194(6)$ & $0.0190(7)$ & $-0.0035(5)$ & $-0.0015(5)$ & $-0.0083(5)$ \\
C1 & $0.0122(6)$ & $0.0189(7)$ & $0.0187(8)$ & $-0.0070(6)$ & $0.0006(5)$ & $-0.0076(6)$ \\
C2 & $0.0201(8)$ & $0.0305(9)$ & $0.0226(9)$ & $0.0009(7)$ & $0.0008(6)$ & $-0.0153(7)$ \\
C3 & $0.0253(9)$ & $0.0306(9)$ & $0.0286(10)$ & $-0.0063(7)$ & $0.0080(7)$ & $-0.0087(7)$ \\
C4 & $0.0423(11)$ & $0.0616(14)$ & $0.0523(14)$ & $-0.0251(10)$ & $0.0112(10)$ & $-0.0445(12)$ \\
C5 & $0.0184(7)$ & $0.0170(7)$ & $0.0221(8)$ & $-0.0032(6)$ & $-0.0043(6)$ & $-0.0053(6)$ \\
C6 & $0.0278(9)$ & $0.0265(9)$ & $0.0297(10)$ & $-0.0086(7)$ & $-0.0116(7)$ & $-0.0057(7)$ \\
C7 & $0.0280(9)$ & $0.0232(8)$ & $0.0295(10)$ & $-0.0081(7)$ & $0.0028(7)$ & $-0.0061(7)$ \\
C11 & $0.0136(6)$ & $0.0116(6)$ & $0.0173(8)$ & $-0.0025(5)$ & $-0.0032(5)$ & $-0.0026(5)$ \\
C12 & $0.0153(7)$ & $0.0211(7)$ & $0.0178(8)$ & $-0.0027(6)$ & $-0.0015(6)$ & $-0.0048(6)$ \\
C13 & $0.0134(7)$ & $0.0265(8)$ & $0.0256(9)$ & $-0.0058(6)$ & $0.0005(6)$ & $-0.0045(7)$ \\
C14 & $0.0154(7)$ & $0.0208(8)$ & $0.0312(9)$ & $-0.0049(6)$ & $-0.0071(6)$ & $-0.0068(7)$ \\
C15 & $0.0217(7)$ & $0.0157(7)$ & $0.0200(8)$ & $-0.0025(6)$ & $-0.0053(6)$ & $-0.0065(6)$ \\
C16 & $0.0159(7)$ & $0.0142(7)$ & $0.0178(8)$ & $-0.0031(5)$ & $-0.0009(6)$ & $-0.0038(6)$ \\
C21 & $0.0192(7)$ & $0.0169(7)$ & $0.0139(7)$ & $-0.0078(6)$ & $0.0014(6)$ & $-0.0058(6)$ \\
C22 & $0.0210(8)$ & $0.0211(8)$ & $0.0230(8)$ & $-0.0084(6)$ & $-0.0041(6)$ & $-0.0029(6)$ \\
C23 & $0.0315(9)$ & $0.0184(8)$ & $0.0249(9)$ & $-0.0081(7)$ & $-0.0041(7)$ & $-0.0019(7)$ \\
C24 & $0.0314(9)$ & $0.0233(8)$ & $0.0192(8)$ & $-0.0168(7)$ & $0.0075(6)$ & $-0.0094(6)$ \\
C25 & $0.0204(8)$ & $0.0312(9)$ & $0.0291(9)$ & $-0.0140(7)$ & $0.0047(7)$ & $-0.0104(7)$ \\
& & & & & &
\end{tabular}




\begin{tabular}{lllllll}
\hline & & & & & \\
C26 & $0.0182(8)$ & $0.0229(8)$ & $0.0264(9)$ & $-0.0060(6)$ & $-0.0006(6)$ & $-0.0036(7)$ \\
C31 & $0.0131(7)$ & $0.0189(7)$ & $0.0179(8)$ & $-0.0054(6)$ & $-0.0003(5)$ & $-0.0071(6)$ \\
C32 & $0.0225(8)$ & $0.0194(8)$ & $0.0260(9)$ & $-0.0062(6)$ & $0.0008(6)$ & $-0.0074(7)$ \\
C33 & $0.0265(8)$ & $0.0225(8)$ & $0.0389(10)$ & $-0.0074(7)$ & $0.0034(7)$ & $-0.0180(8)$ \\
C34 & $0.0241(8)$ & $0.0378(10)$ & $0.0267(9)$ & $-0.0127(7)$ & $0.0062(7)$ & $-0.0212(8)$ \\
C35 & $0.0270(8)$ & $0.0312(9)$ & $0.0189(8)$ & $-0.0134(7)$ & $0.0027(6)$ & $-0.0079(7)$ \\
C36 & $0.0201(7)$ & $0.0201(8)$ & $0.0201(8)$ & $-0.0071(6)$ & $0.0001(6)$ & $-0.0078(6)$ \\
\hline
\end{tabular}

Geometric parameters $\left(\AA,{ }^{\circ}\right)$

\begin{tabular}{|c|c|c|c|}
\hline $\mathrm{Sn}-\mathrm{S} 1$ & $2.4792(4)$ & $\mathrm{C} 12-\mathrm{H} 12$ & 0.9500 \\
\hline $\mathrm{Sn}-\mathrm{S} 2$ & $2.9264(4)$ & $\mathrm{C} 13-\mathrm{C} 14$ & $1.387(3)$ \\
\hline $\mathrm{Sn}-\mathrm{C} 11$ & $2.1446(14)$ & $\mathrm{C} 13-\mathrm{H} 13$ & 0.9500 \\
\hline $\mathrm{Sn}-\mathrm{C} 21$ & $2.1349(15)$ & $\mathrm{C} 14-\mathrm{C} 15$ & $1.391(2)$ \\
\hline $\mathrm{Sn}-\mathrm{C} 31$ & $2.1754(15)$ & C14-H14 & 0.9500 \\
\hline $\mathrm{C} 1-\mathrm{S} 1$ & $1.7587(15)$ & $\mathrm{C} 15-\mathrm{C} 16$ & $1.388(2)$ \\
\hline $\mathrm{C} 1-\mathrm{S} 2$ & $1.7006(16)$ & C15-H15 & 0.9500 \\
\hline $\mathrm{C} 1-\mathrm{N} 1$ & $1.336(2)$ & $\mathrm{C} 16-\mathrm{H} 16$ & 0.9500 \\
\hline $\mathrm{C} 5-\mathrm{N} 1$ & $1.495(2)$ & $\mathrm{C} 21-\mathrm{C} 26$ & $1.391(2)$ \\
\hline $\mathrm{C} 2-\mathrm{N} 1$ & $1.497(2)$ & $\mathrm{C} 21-\mathrm{C} 22$ & $1.394(2)$ \\
\hline $\mathrm{C} 2-\mathrm{C} 3$ & $1.517(2)$ & $\mathrm{C} 22-\mathrm{C} 23$ & $1.387(2)$ \\
\hline $\mathrm{C} 2-\mathrm{C} 4$ & $1.519(3)$ & $\mathrm{C} 22-\mathrm{H} 22$ & 0.9500 \\
\hline $\mathrm{C} 2-\mathrm{H} 2$ & 1.0000 & $\mathrm{C} 23-\mathrm{C} 24$ & $1.383(2)$ \\
\hline $\mathrm{C} 3-\mathrm{H} 3 \mathrm{~A}$ & 0.9800 & $\mathrm{C} 23-\mathrm{H} 23$ & 0.9500 \\
\hline C $3-\mathrm{H} 3 \mathrm{~B}$ & 0.9800 & $\mathrm{C} 24-\mathrm{C} 25$ & $1.385(3)$ \\
\hline $\mathrm{C} 3-\mathrm{H} 3 \mathrm{C}$ & 0.9800 & $\mathrm{C} 24-\mathrm{H} 24$ & 0.9500 \\
\hline $\mathrm{C} 4-\mathrm{H} 4 \mathrm{~A}$ & 0.9800 & $\mathrm{C} 25-\mathrm{C} 26$ & $1.387(2)$ \\
\hline $\mathrm{C} 4-\mathrm{H} 4 \mathrm{~B}$ & 0.9800 & $\mathrm{C} 25-\mathrm{H} 25$ & 0.9500 \\
\hline $\mathrm{C} 4-\mathrm{H} 4 \mathrm{C}$ & 0.9800 & $\mathrm{C} 26-\mathrm{H} 26$ & 0.9500 \\
\hline $\mathrm{C} 5-\mathrm{C} 7$ & $1.515(2)$ & $\mathrm{C} 31-\mathrm{C} 32$ & $1.397(2)$ \\
\hline $\mathrm{C} 5-\mathrm{C} 6$ & $1.519(2)$ & $\mathrm{C} 31-\mathrm{C} 36$ & $1.396(2)$ \\
\hline $\mathrm{C} 5-\mathrm{H} 5$ & 1.0000 & $\mathrm{C} 32-\mathrm{C} 33$ & $1.391(3)$ \\
\hline C6-H6A & 0.9800 & $\mathrm{C} 32-\mathrm{H} 32$ & 0.9500 \\
\hline C6-H6B & 0.9800 & $\mathrm{C} 33-\mathrm{C} 34$ & $1.382(3)$ \\
\hline C6-H6C & 0.9800 & C $33-\mathrm{H} 33$ & 0.9500 \\
\hline C7-H7A & 0.9800 & $\mathrm{C} 34-\mathrm{C} 35$ & $1.388(3)$ \\
\hline C7-H7B & 0.9800 & C $34-\mathrm{H} 34$ & 0.9500 \\
\hline $\mathrm{C} 7-\mathrm{H} 7 \mathrm{C}$ & 0.9800 & $\mathrm{C} 35-\mathrm{C} 36$ & $1.390(2)$ \\
\hline $\mathrm{C} 11-\mathrm{C} 12$ & $1.395(2)$ & C35-H35 & 0.9500 \\
\hline $\mathrm{C} 11-\mathrm{C} 16$ & $1.397(2)$ & $\mathrm{C} 36-\mathrm{H} 36$ & 0.9500 \\
\hline $\mathrm{C} 12-\mathrm{C} 13$ & $1.388(2)$ & & \\
\hline $\mathrm{C} 21-\mathrm{Sn}-\mathrm{C} 11$ & $119.87(6)$ & $\mathrm{C} 12-\mathrm{C} 11-\mathrm{C} 16$ & $118.47(14)$ \\
\hline $\mathrm{C} 21-\mathrm{Sn}-\mathrm{C} 31$ & $102.73(6)$ & $\mathrm{C} 12-\mathrm{C} 11-\mathrm{Sn}$ & $117.04(11)$ \\
\hline $\mathrm{C} 11-\mathrm{Sn}-\mathrm{C} 31$ & $103.38(5)$ & $\mathrm{C} 16-\mathrm{C} 11-\mathrm{Sn}$ & $124.47(11)$ \\
\hline $\mathrm{C} 21-\mathrm{Sn}-\mathrm{S} 1$ & $112.27(4)$ & $\mathrm{C} 13-\mathrm{C} 12-\mathrm{C} 11$ & $120.79(15)$ \\
\hline $\mathrm{C} 11-\mathrm{Sn}-\mathrm{S} 1$ & $119.12(4)$ & $\mathrm{C} 13-\mathrm{C} 12-\mathrm{H} 12$ & 119.6 \\
\hline $\mathrm{C} 31-\mathrm{Sn}-\mathrm{S} 1$ & $93.24(4)$ & $\mathrm{C} 11-\mathrm{C} 12-\mathrm{H} 12$ & 119.6 \\
\hline
\end{tabular}




\begin{tabular}{|c|c|c|c|}
\hline $\mathrm{C} 21-\mathrm{Sn}-\mathrm{S} 2$ & $88.10(4)$ & $\mathrm{C} 14-\mathrm{C} 13-\mathrm{C} 12$ & $120.24(15)$ \\
\hline $\mathrm{C} 11-\mathrm{Sn}-\mathrm{S} 2$ & $86.68(4)$ & $\mathrm{C} 14-\mathrm{C} 13-\mathrm{H} 13$ & 119.9 \\
\hline $\mathrm{C} 31-\mathrm{Sn}-\mathrm{S} 2$ & $158.41(4)$ & $\mathrm{C} 12-\mathrm{C} 13-\mathrm{H} 13$ & 119.9 \\
\hline $\mathrm{S} 1-\mathrm{Sn}-\mathrm{S} 2$ & $65.260(11)$ & $\mathrm{C} 13-\mathrm{C} 14-\mathrm{C} 15$ & $119.49(15)$ \\
\hline $\mathrm{C} 1-\mathrm{S} 1-\mathrm{Sn}$ & $95.87(5)$ & $\mathrm{C} 13-\mathrm{C} 14-\mathrm{H} 14$ & 120.3 \\
\hline $\mathrm{C} 1-\mathrm{S} 2-\mathrm{Sn}$ & $82.36(5)$ & $\mathrm{C} 15-\mathrm{C} 14-\mathrm{H} 14$ & 120.3 \\
\hline $\mathrm{C} 1-\mathrm{N} 1-\mathrm{C} 5$ & $125.74(13)$ & $\mathrm{C} 14-\mathrm{C} 15-\mathrm{C} 16$ & $120.21(15)$ \\
\hline $\mathrm{C} 1-\mathrm{N} 1-\mathrm{C} 2$ & $119.61(13)$ & $\mathrm{C} 14-\mathrm{C} 15-\mathrm{H} 15$ & 119.9 \\
\hline $\mathrm{C} 5-\mathrm{N} 1-\mathrm{C} 2$ & $114.62(12)$ & $\mathrm{C} 16-\mathrm{C} 15-\mathrm{H} 15$ & 119.9 \\
\hline $\mathrm{N} 1-\mathrm{C} 1-\mathrm{S} 2$ & $123.73(12)$ & $\mathrm{C} 15-\mathrm{C} 16-\mathrm{C} 11$ & $120.71(14)$ \\
\hline $\mathrm{N} 1-\mathrm{C} 1-\mathrm{S} 1$ & $119.94(12)$ & $\mathrm{C} 15-\mathrm{C} 16-\mathrm{H} 16$ & 119.6 \\
\hline $\mathrm{S} 2-\mathrm{C} 1-\mathrm{S} 1$ & $116.33(8)$ & $\mathrm{C} 11-\mathrm{C} 16-\mathrm{H} 16$ & 119.6 \\
\hline $\mathrm{N} 1-\mathrm{C} 2-\mathrm{C} 3$ & $111.83(14)$ & $\mathrm{C} 26-\mathrm{C} 21-\mathrm{C} 22$ & $118.14(14)$ \\
\hline $\mathrm{N} 1-\mathrm{C} 2-\mathrm{C} 4$ & $110.44(15)$ & $\mathrm{C} 26-\mathrm{C} 21-\mathrm{Sn}$ & $119.77(11)$ \\
\hline $\mathrm{C} 3-\mathrm{C} 2-\mathrm{C} 4$ & $112.51(15)$ & $\mathrm{C} 22-\mathrm{C} 21-\mathrm{Sn}$ & $121.95(11)$ \\
\hline $\mathrm{N} 1-\mathrm{C} 2-\mathrm{H} 2$ & 107.3 & $\mathrm{C} 23-\mathrm{C} 22-\mathrm{C} 21$ & $120.74(15)$ \\
\hline $\mathrm{C} 3-\mathrm{C} 2-\mathrm{H} 2$ & 107.3 & $\mathrm{C} 23-\mathrm{C} 22-\mathrm{H} 22$ & 119.6 \\
\hline $\mathrm{C} 4-\mathrm{C} 2-\mathrm{H} 2$ & 107.3 & $\mathrm{C} 21-\mathrm{C} 22-\mathrm{H} 22$ & 119.6 \\
\hline $\mathrm{C} 2-\mathrm{C} 3-\mathrm{H} 3 \mathrm{~A}$ & 109.5 & $\mathrm{C} 24-\mathrm{C} 23-\mathrm{C} 22$ & $120.43(15)$ \\
\hline $\mathrm{C} 2-\mathrm{C} 3-\mathrm{H} 3 \mathrm{~B}$ & 109.5 & $\mathrm{C} 24-\mathrm{C} 23-\mathrm{H} 23$ & 119.8 \\
\hline $\mathrm{H} 3 \mathrm{~A}-\mathrm{C} 3-\mathrm{H} 3 \mathrm{~B}$ & 109.5 & $\mathrm{C} 22-\mathrm{C} 23-\mathrm{H} 23$ & 119.8 \\
\hline $\mathrm{C} 2-\mathrm{C} 3-\mathrm{H} 3 \mathrm{C}$ & 109.5 & $\mathrm{C} 23-\mathrm{C} 24-\mathrm{C} 25$ & $119.52(15)$ \\
\hline $\mathrm{H} 3 \mathrm{~A}-\mathrm{C} 3-\mathrm{H} 3 \mathrm{C}$ & 109.5 & $\mathrm{C} 23-\mathrm{C} 24-\mathrm{H} 24$ & 120.2 \\
\hline $\mathrm{H} 3 \mathrm{~B}-\mathrm{C} 3-\mathrm{H} 3 \mathrm{C}$ & 109.5 & $\mathrm{C} 25-\mathrm{C} 24-\mathrm{H} 24$ & 120.2 \\
\hline $\mathrm{C} 2-\mathrm{C} 4-\mathrm{H} 4 \mathrm{~A}$ & 109.5 & $\mathrm{C} 24-\mathrm{C} 25-\mathrm{C} 26$ & $119.94(15)$ \\
\hline $\mathrm{C} 2-\mathrm{C} 4-\mathrm{H} 4 \mathrm{~B}$ & 109.5 & $\mathrm{C} 24-\mathrm{C} 25-\mathrm{H} 25$ & 120.0 \\
\hline $\mathrm{H} 4 \mathrm{~A}-\mathrm{C} 4-\mathrm{H} 4 \mathrm{~B}$ & 109.5 & $\mathrm{C} 26-\mathrm{C} 25-\mathrm{H} 25$ & 120.0 \\
\hline $\mathrm{C} 2-\mathrm{C} 4-\mathrm{H} 4 \mathrm{C}$ & 109.5 & $\mathrm{C} 21-\mathrm{C} 26-\mathrm{C} 25$ & $121.22(15)$ \\
\hline $\mathrm{H} 4 \mathrm{~A}-\mathrm{C} 4-\mathrm{H} 4 \mathrm{C}$ & 109.5 & $\mathrm{C} 21-\mathrm{C} 26-\mathrm{H} 26$ & 119.4 \\
\hline $\mathrm{H} 4 \mathrm{~B}-\mathrm{C} 4-\mathrm{H} 4 \mathrm{C}$ & 109.5 & $\mathrm{C} 25-\mathrm{C} 26-\mathrm{H} 26$ & 119.4 \\
\hline $\mathrm{N} 1-\mathrm{C} 5-\mathrm{C} 7$ & $113.59(13)$ & $\mathrm{C} 32-\mathrm{C} 31-\mathrm{C} 36$ & $117.70(14)$ \\
\hline $\mathrm{N} 1-\mathrm{C} 5-\mathrm{C} 6$ & $112.50(13)$ & $\mathrm{C} 32-\mathrm{C} 31-\mathrm{Sn}$ & $120.43(12)$ \\
\hline $\mathrm{C} 7-\mathrm{C} 5-\mathrm{C} 6$ & $114.30(15)$ & $\mathrm{C} 36-\mathrm{C} 31-\mathrm{Sn}$ & $121.81(11)$ \\
\hline $\mathrm{N} 1-\mathrm{C} 5-\mathrm{H} 5$ & 105.1 & $\mathrm{C} 33-\mathrm{C} 32-\mathrm{C} 31$ & $120.96(16)$ \\
\hline $\mathrm{C} 7-\mathrm{C} 5-\mathrm{H} 5$ & 105.1 & $\mathrm{C} 33-\mathrm{C} 32-\mathrm{H} 32$ & 119.5 \\
\hline $\mathrm{C} 6-\mathrm{C} 5-\mathrm{H} 5$ & 105.1 & $\mathrm{C} 31-\mathrm{C} 32-\mathrm{H} 32$ & 119.5 \\
\hline $\mathrm{C} 5-\mathrm{C} 6-\mathrm{H} 6 \mathrm{~A}$ & 109.5 & $\mathrm{C} 34-\mathrm{C} 33-\mathrm{C} 32$ & $120.27(16)$ \\
\hline $\mathrm{C} 5-\mathrm{C} 6-\mathrm{H} 6 \mathrm{~B}$ & 109.5 & $\mathrm{C} 34-\mathrm{C} 33-\mathrm{H} 33$ & 119.9 \\
\hline $\mathrm{H} 6 \mathrm{~A}-\mathrm{C} 6-\mathrm{H} 6 \mathrm{~B}$ & 109.5 & $\mathrm{C} 32-\mathrm{C} 33-\mathrm{H} 33$ & 119.9 \\
\hline $\mathrm{C} 5-\mathrm{C} 6-\mathrm{H} 6 \mathrm{C}$ & 109.5 & $\mathrm{C} 33-\mathrm{C} 34-\mathrm{C} 35$ & $119.89(16)$ \\
\hline $\mathrm{H} 6 \mathrm{~A}-\mathrm{C} 6-\mathrm{H} 6 \mathrm{C}$ & 109.5 & $\mathrm{C} 33-\mathrm{C} 34-\mathrm{H} 34$ & 120.1 \\
\hline $\mathrm{H} 6 \mathrm{~B}-\mathrm{C} 6-\mathrm{H} 6 \mathrm{C}$ & 109.5 & $\mathrm{C} 35-\mathrm{C} 34-\mathrm{H} 34$ & 120.1 \\
\hline $\mathrm{C} 5-\mathrm{C} 7-\mathrm{H} 7 \mathrm{~A}$ & 109.5 & $\mathrm{C} 36-\mathrm{C} 35-\mathrm{C} 34$ & $119.53(16)$ \\
\hline $\mathrm{C} 5-\mathrm{C} 7-\mathrm{H} 7 \mathrm{~B}$ & 109.5 & $\mathrm{C} 36-\mathrm{C} 35-\mathrm{H} 35$ & 120.2 \\
\hline $\mathrm{H} 7 \mathrm{~A}-\mathrm{C} 7-\mathrm{H} 7 \mathrm{~B}$ & 109.5 & C $34-\mathrm{C} 35-\mathrm{H} 35$ & 120.2 \\
\hline $\mathrm{C} 5-\mathrm{C} 7-\mathrm{H} 7 \mathrm{C}$ & 109.5 & $\mathrm{C} 35-\mathrm{C} 36-\mathrm{C} 31$ & $121.64(15)$ \\
\hline $\mathrm{H} 7 \mathrm{~A}-\mathrm{C} 7-\mathrm{H} 7 \mathrm{C}$ & 109.5 & $\mathrm{C} 35-\mathrm{C} 36-\mathrm{H} 36$ & 119.2 \\
\hline $\mathrm{H} 7 \mathrm{~B}-\mathrm{C} 7-\mathrm{H} 7 \mathrm{C}$ & 109.5 & $\mathrm{C} 31-\mathrm{C} 36-\mathrm{H} 36$ & 119.2 \\
\hline
\end{tabular}




$\begin{array}{ll}\mathrm{C} 5-\mathrm{N} 1-\mathrm{C} 1-\mathrm{S} 2 & 178.33(11) \\ \mathrm{C} 2-\mathrm{N} 1-\mathrm{C} 1-\mathrm{S} 2 & 0.0(2) \\ \mathrm{C} 5-\mathrm{N} 1-\mathrm{C} 1-\mathrm{S} 1 & -2.2(2) \\ \mathrm{C} 2-\mathrm{N} 1-\mathrm{C} 1-\mathrm{S} 1 & 179.49(11) \\ \mathrm{S} n-\mathrm{S} 2-\mathrm{C} 1-\mathrm{N} 1 & -176.75(13) \\ \mathrm{S} n-\mathrm{S} 2-\mathrm{C} 1-\mathrm{S} 1 & 3.78(7) \\ \mathrm{S} n-\mathrm{S} 1-\mathrm{C} 1-\mathrm{N} 1 & 176.06(11) \\ \mathrm{S} n-\mathrm{S} 1-\mathrm{C} 1-\mathrm{S} 2 & -4.44(8) \\ \mathrm{C} 1-\mathrm{N} 1-\mathrm{C} 2-\mathrm{C} 3 & -120.82(16) \\ \mathrm{C} 5-\mathrm{N} 1-\mathrm{C} 2-\mathrm{C} 3 & 60.70(19) \\ \mathrm{C} 1-\mathrm{N} 1-\mathrm{C} 2-\mathrm{C} 4 & 113.06(18) \\ \mathrm{C} 5-\mathrm{N} 1-\mathrm{C} 2-\mathrm{C} 4 & -65.42(18) \\ \mathrm{C} 1-\mathrm{N} 1-\mathrm{C} 5-\mathrm{C} 7 & -64.0(2) \\ \mathrm{C} 2-\mathrm{N} 1-\mathrm{C} 5-\mathrm{C} 7 & 114.38(15) \\ \mathrm{C} 1-\mathrm{N} 1-\mathrm{C} 5-\mathrm{C} 6 & 67.84(19) \\ \mathrm{C} 2-\mathrm{N} 1-\mathrm{C} 5-\mathrm{C} 6 & -113.79(15) \\ \mathrm{C} 16-\mathrm{C} 11-\mathrm{C} 12-\mathrm{C} 13 & -1.6(2) \\ \mathrm{S} n-\mathrm{C} 11-\mathrm{C} 12-\mathrm{C} 13 & 176.97(12) \\ \mathrm{C} 11-\mathrm{C} 12-\mathrm{C} 13-\mathrm{C} 14 & 2.7(2) \\ \mathrm{C} 12-\mathrm{C} 13-\mathrm{C} 14-\mathrm{C} 15 & -1.3(2) \\ \end{array}$

$-1.3(2)$

$2.4(2)$

$-0.9(2)$

$-179.42(11)$

$-0.9(2)$

$-176.59(13)$

$0.8(3)$

$0.1(3)$

$-0.9(3)$

$0.1(2)$

$175.91(13)$

$0.8(3)$

$-0.8(2)$

$176.56(12)$

$0.1(3)$

$0.5(3)$

$-0.3(3)$

$-0.4(2)$

$1.0(2)$

$-176.35(12)$

Hydrogen-bond geometry $\left(A,{ }^{\circ}\right)$

\begin{tabular}{lllll}
\hline$D-\mathrm{H} \cdots A$ & $D-\mathrm{H}$ & $\mathrm{H} \cdots A$ & $D \cdots A$ & $D-\mathrm{H} \cdots A$ \\
\hline $\mathrm{C} 34-\mathrm{H} 34 \cdots \mathrm{C} 24^{\mathrm{i}}$ & 0.95 & 2.82 & $3.757(3)$ & 171 \\
\hline
\end{tabular}

Symmetry code: (i) $-x+1,-y,-z$. 